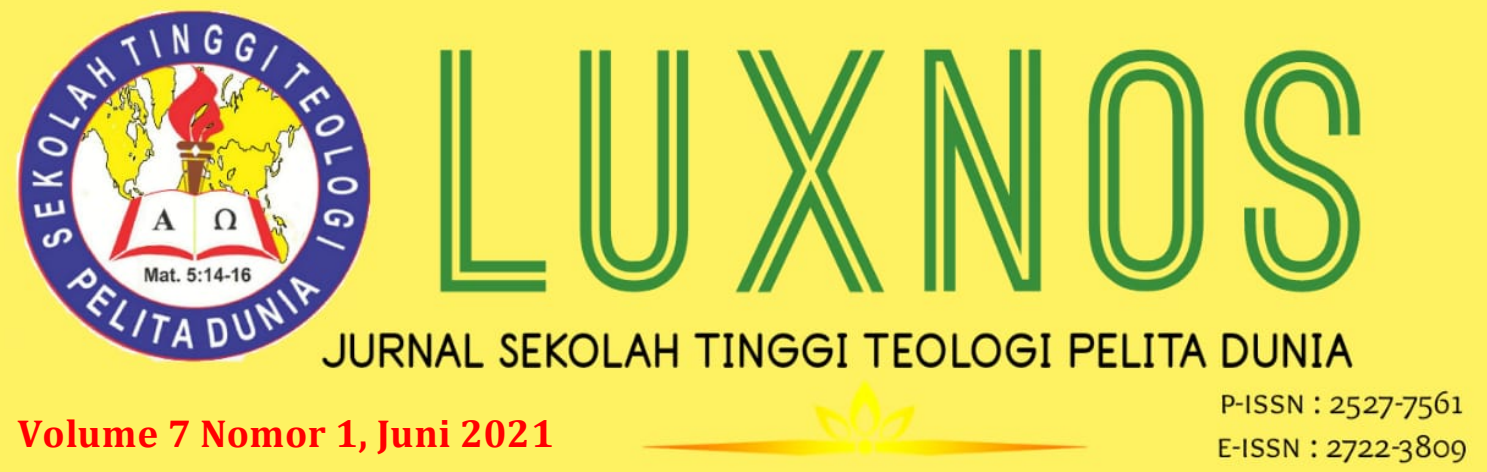

\title{
Peran Orangtua Mendidik Spiritual Anak Di Era Revolusi Industri 4.0 Berdasarkan Ulangan 6:4-9 (Tinjauan Teologis dan Pedagogis Dalam Pendidikan Agama Kristen)
}

\author{
Abraham Tefbana \\ Sekolah Tinggi Teologi Pelita Dunia, Tangerang \\ tefbana.abraham@gmail.com
}

\begin{abstract}
The writing of this article is to explain the role of parents as spiritual educators of children in the era of the industrial revolution 4.0 based on Ul. 6:4-9. God gave a mandate to parents to educate and be an example for the spiritual growth of their children. The implementation of religious education for the Israelites is centered on: (1). His identity as God's chosen people; (2). God's self-revelation (revelation and spiritual experience with God); (3). Statement as the image of God. Millennial generation parents in the era of the industrial revolution 4.0, are required to be creative and innovative in implementing Ul. 6:4-9 in forms such as spiritual animated films and spiritual cartoons that attract children's interest and attention to learn God's word according to the era of the industrial revolution 4.0. This study uses a descriptive qualitative method to explain the role of parents in teaching Ul. 6:4-9 in the context of the time of Moses with the era of the industrial revolution 4.0 with the aim of forming children's spirituality. Keywords: Role of Parents, Spiritual Educators, Industrial Revolution 4.0.
\end{abstract}

Abstrak: Penulisan artikel ini bertujuan untuk menjelaskan tentang peran orangtua sebagai pendidik spiritual anak di era revolusi industri 4.0 berlandaskan Ul. 6:4-9. Pendidikan spiritual anak adalah mandat Allah kepada setiap orangtua untuk mendidik dan menjadi teladan bagi pertumbuhan spiritual anak-anaknya. Pelaksanaan pendidikan agama bagi bangsa Israel berpusat pada: (1). Identitasnya sebagai umat pilihan Allah; (2). Penyataan diri Allah (wahyu dan pengalaman spiritual dengan Allah); (3). Pernyataan sebagai gambar Allah. Para orangtua generasi milenial dituntut agar kreatif dan inovatif untuk menerapkan Ul. 6:4-9 di era komunikasi berbasis digital dalam bentuk seperti film-film animasi rohani dan film-film kartun rohani yang menarik minat dan perhatian anak-anak 


\section{JURNAL LUXNOS}

Volume 7 Nomor 1, Juni 2021

untuk belajar firman Tuhan sesuai tuntutan perkembangan zaman. Metode yang digunakan dalam penelitian adalah metode kualitatif deskriptif dalam menjelaskan peran orangtua dalam mengajarkan Ul. 6:4-9 pada konteks zaman Musa dengan konteks revolusi industri 4.0 dengan tujuan untuk pembentuk spiritual anak.

Kata kunci: Peran Orangtua, Pendidik Spiritual, Revolusi Industri 4.0.

\section{Pendahuluan}

Sejak zaman Perjanjian Lama, Allah memberikan mandat kepada para orangtua sebagai pendidik kerohanian anak-anak (Ul. 6:4-9). Bagi bangsa Israel Pendidikan agama merupakan bagian inti dari kegiatan kehidupan sehari-hari yang harus dilakukan secara teratur dan tertib mulai dari keluarga. Untuk memenuhi syarat pendidikan agama yang dimandatkan Allah, para orangtua Israel dituntut untuk belajar seumur hidupnya agar bisa mengajar anak-anaknya. Meskipun dari sejarah kuno nyata bahwa tugas mulia itu jarang sekali dilaksanakan secara tuntas sesuai dengan harapan yang tertuang dalam penglihatan mulia tersebut, namun ia merupakan suatu patokan bagi keluarga Yahudi. ${ }^{1}$ Bagi bangsa Israel, kunci kesuksesan anak-anak adalah pendidikan, dan kunci kesuksesan anak-anak dalam pendidikan ada pada peran dan tanggung jawab orangtua. Bagi bangsa Israel, kunci kesuksesan anak-anak adalah pendidikan, dan peran juga tanggung jawab orangtua. Dasar pendidikan agama Yahudi yang berpusat pada identitasnya sebagai bangsa pilihan Allah, yang menerima penyataan Allah melalui firman-Nya, dan ajaran tentang manusia sebagai gambar dan rupa Allah.

Pendidikan Kristen dapat dilaksanakan di keluarga, gereja, dan masyarakat. ${ }^{2}$ Keluarga merupakan komunitas terkecil di masyarakat, namun memberi pengaruh yang cukup besar terhadap gereja dan masyarakat. Oleh karena itu, Allah memberi mandat kepada orangtua sebagai pemimpin keluraga untuk berperan sebagai pendidik bagi spiritual dan karakter anak-anaknya. Sebab pengetahuan anak lebih mudah untuk diubah, berbeda dengan spiritual dan karakter yang butuh keteladanan dan pembiasaan. Orangtua sanggup dan dengan mudah mempengaruhi spiritual dan karakter anak-anaknya karena faktor hubungan dan keteladanan

Pratama mengungkapkan bahwa perkembangan zaman menuntut orangtua belajar mengikuti berbagai perubahan yang begitu cepat, sebagai dampak

1 Robert R. Boehlke, Sejarah Perkembangan Pikiran Dan Praktek Pendidikan Agama Kristen Dari Plato Sampai IG. Loyola, (Jakarta: BPK Gunung Mulia, 2006), 19.

2 Iris V. Cully, Dinamika Pendidikan Kristen (Jakarta: BPK. Gunung Mulia, 2009). 
perkembangan teknologi. ${ }^{3}$ Dalam peran sebagai pengajar dan pembimbingan spiritual anak, orangtua dituntut untuk memahami cara mengoperasikan teknologi komunikasi berbasis digital, agar dapat membimbing anak dalam menggunakan telepon genggamnya untuk belajar firman (membaca Alkitab, menonton film-film kartun tentang Alkitab dan berbagai fitur rohani kristen lainnya). Terlebih di masa pandemi covid-19 sekarang ini, anak-anak/peserta didik diwajibkan untuk belajar secara virtual menggunakan laptop atau telepon genggam, sehingga orangtua yang sebelumnya melarang anak kini harus dibelikan. Bahkan orangtua harus belajar ekstra karena mendadak jadi guru pendamping anak dalam belajar.

\section{Metode Penelitian}

Pendekatan dalam penelitian ini adalah kualitatif dan deskriptif untuk mendeskripsikan tentang peran orangtua sebagai pendidik spiritual anak sesuai Ulangan 6:4-9 dan implementasinya di Era Revolusi Industri 4.0. Pendekatan penelitian kualitatif untuk menjelaskan dan mengedukasi para orangtua untuk tahu perannya dalam mendidik anak sesuai Alkitab di era Revolusi Industri 4.0.

Sedang pengertian deskriptif yaitu menggambarkan apa adanya. 4 Menggambarkan dan mendeskripsikan peran orangtua dalam mendidik spiritual anak melalui firman Tuhan (Ul. 6:4-9) dalam mengantisipasi dampak negatif era digital. Cara orangtua mendidik spiritual anak di era Revolusi Industri 4.0 adalah mendamping anak agar membaca Alkitab digital, nonton film-film kartun rohani Kristen dan berbagai vitur rohani lainnya dari telepon genggam.

\section{Hasil Temuan Penelitian}

\section{A. Peran Orangtua Sebagai Pendidik Spiritual Anak}

Peran orangtua sebagai pendidik pertama bagi pertumbuhan spiritual anakanak sesuai mandat Allah kepada manusia (Ul. 6:4-9). Menurut Tanusaputra bahwa orangtua sebagai pendidik yang bertanggungjawab untuk menciptakan lingkungan belajar anak di keluarga yang aman dan nyaman bagi anak untuk belajar dan bertumbuh untuk menjadi dewasa. ${ }^{5}$ Orangtua pendidik pertama yang bertanggungjawab terhadap pertumbuhan kerohanian anak-anaknya. Pembentukan spiritual anak-anak menuntut orangtua untuk belajar firman Tuhan dan menjadi teladan bagi anak-anak.

${ }^{3}$ H. Ch Pratama, Cyber Smart Parenting: Kiat Sukses Menghadapi dan Mengasuh Generasi Digital. (Bandung: Visi Pres, 2002).

${ }^{4}$ Bahasa. Bahasa, Kamus Besar Bahasa Indonesia, 22 April 2020.

5 D.Tanusaputra, "Teologi Pernikahan dan Keluarga," Veritas: Jurnal Teologi dan Pelayanan 6, no. 1 (2 005): 73-101. 


\section{JURNAL LUXNOS}

Volume 7 Nomor 1, Juni 2021

Keluarga merupakan komunitas Kristen terkecil dalam mengajarkan firman Tuhan bagi pertumbuhan spiritual anak-anaknya. Orangtua berperan sebagai pendidik bagi pertumbuhan spiritual anak-anaknya sesuai mandat Allah kepada Musa. Implementasi Ul. 6:4-9 di era Musa konteksnya berbeda dengan saat ini di era Revolusi Industri 4.0. Oleh karena itu, orangtua milenial harus memahami pembelajaran firman Tuhan seperti membaca Alkitab menggunakan Laptop, Note book, Ipad dan telepon ganggam.

Panggabean mengatakan bahwa Prinsip teologi yang jelas menjadi landasan praktek kehidupan Kristen, yang membawa pemengaruh dalam praktek iman Kristen. ${ }^{6}$ Fondasi pendidikan Kristen dikonstruksi berdasarkan Ulangan 6:4-9, termasuk peran orangtua sebagai pendidik spiritual anak juga merupakan amanat Allah. Dengan anak menggunakan telepon gengam untuk belajar firman Tuhan melalui berbagai aplikasi, maka secara tidak langsung menjadi tuntutan para orangtua untuk belajar mengenal dan menguasai teknologi komunikasi berbasis digital.

\section{B. Tinjauan Teologis dan Pedagogis Ul. 6:4-9}

Bila peran orangtua sebagai pendidik spiritual anak dipahami dari mandat Allah, maka mendidik anak dalam iman Kristen, orangtua diposisikan sebagai wakil Allah dalam tugas dan untuk mendidik anak-anak menjadi dewasa dalam iamn kepada Allah. ${ }^{7}$ Sebagai wakil Allah dalam mendidik, maka orangtua bertanggungjawab kepada Allah terhadap masa depan keselamatan anak-anak.

Dalam peran orangtua mendidik anak berdasarkan (Ul. 6:4-9) Allah memberikan materi, mandate, dan metode kepada para orangtua bangsa Israel untuk berperan sebagai pendidik spiritual anak-anaknya. Berikut ini pembahasan tentang materi (ay. 4-5), mandat (ay. 6-7) dan metode (8-9) peran orangtua sebagai pendidik spiritual anak. Pembahasan ini dapat diimplementasikan di era Revolusi Industri 4.0 menggunakan teknologi komunikasi digital.

\section{Materi ajar (Ul. 6:4-5)}

Ul. 6:4-5 merupakan konten utama dalam materi ajar kepada anak-anak. Orangtua dapat mencari dan menemukan dari internet konten-konten kreatif dan inovatif sebagai materi yang dikembangkan untuk mengajar anak-anak.

6 J. Zeni dan Z. Panggabean, "Pendekatan Praksis-Teologis Dalam Fondasi Pendidikan Kristiani," KURIOS (Jurnal Teologi dan Pendidikan Agama Kristen) 4, no. 2 (2018): 167-181, http:/ / www.sttpb.ac.id/e-journal/index.php/kurios/article/view/81.

7 Stephen Tong, Arsitektur Jiwa (Jakarta: LRII, 1991), 13. 
Esensi materi Pendidikan Agama Kristen dalam mengajar bagi pertumbuhan spiritual anak-anak adalah:

a. Dengarlah, hai orang Israel (Ul. 6:4a).

Ungkapan "Dengarlah, hai orang Israel” tentang kehadiran Allah sebagai pemimpin bangsa Israel, maka Musa terus-menerus mengumumkan kekhususan atau kekudusan Allah dan jawaban bangsa Israel dalam kesetiaan yang terfokus kepada Allah. Kata "dengarlah" diartikan sebagai "ketaatan", yang juga menggambarkan pikiran yang berserah dan tunduk kepada otoritas Allah. William Dyrness menjelaskan bahwa, telah dimengerti bahwa ketaatan adalah jalan menuju hidup (Ul. 30:15-20), tetapi ini hanya karena ketaatan seperti ini merupakan hakikat hidup yang sesungguhnya, bukan karena mekanisme untuk mencapai tujuan tersebut.8 "Dengarlah" sebagai himbauan Musa kepada bangsa Israel, agar mengasihi, mentaati dan menghormati Allah yang Esa yaitu Allah Abraham, Ishak dan Yakob dan hidup dalam persekutuan dengan-Nya untuk selama-lamanya.

b. TUHAN itu Allah kita, TUHAN itu Esa! (Ul. 6:4b).

Nama Allah yang paling penting dan paling sering dipakai dalam Alkitab Ibrani adalah Yahweh atau dikenal dengan sebutan Tetragrammaton, empat huruf nama Allah dalam bahasa Ibrani: YHWH. Dalam teks kata Yahweh tertulis YHWH, tetapi orang harus mengucapkannya Adonai yang berarti "tuan" atau "TUHAN". 9 Dalam agama Yahudi diajarkan bahwa YHWH adalah nama Allah yang sangat sakral sehingga tidak disebutkan di dalam Shema Israel, sehingga diganti dengan Adonai. Kata "Adonai" adalah bentuk jamak dari kata "adon" yang berarti tuan, pemilik, penguasa dan junjungan. ${ }^{10}$ Karena YHWH merupakan nama Allah yang terlalu suci untuk disebutkan dalam Shema Israel, sehingga dipakai "Adonai" penulisannya dalam Shema sebagai berikut: "Shema Yisrael Adonai Eloheinu Adonai Ehad." Pengertian harafiahnya secara leksikal adalah Shema - "Dengarkanlah" dan "berlakulah"; Yisrael - Israel, umat pilihan Adona; Adonai artinya "tuan" dipakai untuk ganti istilah Tetragrammaton. ${ }^{11}$ Dalam hubungannya dengan nama Allah, kata "adonai" untuk menggantikan $Y H W H$ dalam teks asli Ibrani, karena orang Yahudi tidak boleh menyebut nama $Y H W H$, tapi Adonai yang berarti TUHAN.

8 William Dyrness, Tema-Tema Dalam Teologi Perjanjian Lama, (Malang: Gandum Mas, 1979), 111.

${ }^{9}$ Samuel Santoso, Berteologi Di Tengah Perubahan (Jakarta: Sinode GKI, 2007)

${ }_{10}$ Martinus T. Mawene, Perjanjian Lama Dan Teologi Kontekstual (Jakarta: BPK. Gunung Mulia, 2008), 27.

${ }^{11}$ Sentot Sadono, Doktrin Baptis, Di Antara Pandangan Teologi Kristen (Semarang: Psca Sarjara STBI, 2011), 10. 
Yahweh adalah Allah yang satu-satunya. Itulah sebabnya Perjanjian Lama dapat menggunakan berbagai nama untuk Allah: kadang-kadang Dia disebut EL, Elohim, Eloah, namun selalu yang dimaksud ialah Yahweh. ${ }^{12}$ Karena nama YHWH terlalu suci untuk disebut secara bebas, maka digunakan berbagai nama sebutan untuk menyebut atau memanggil Allah. Yehova atau Yahweh merupakan nama pribadi yang paling baik dari Allah Israel. Istilah ini dikaitkan dengan kata kerja Ibrani "ada", yang berarti "dia yang ada dengan sendirinya," atau "dia yang menjadikan ada (Kel. 6:2; band. 3:13-16).13 Kata "Dengarlah" berhubungan dengan otoritas Allah sebagai pencipta, yang menciptakan dari tidak ada menjadi ada. Sedang pernyataan "Tuhan itu Esa", menunjuk pada monoteisme yang makna teologisnya sangat dalam, sehingga menuntut kesungguhan dari para pendengar yang harus penuh perhatian. "TUHAN itu Allah kita, TUHAN itu esa," sebagai pengakuan yang dapat diterjemahkan sebagai pernyataan monoteisme. Allah itu unik; dan keilahian itu adalah milik-Nya semata. ${ }^{14}$ Sifat yang unik dari Allah, karena pemerintahan Israel diberikan langsung oleh Allah, maka tidak terdapat persamaan yang cocok dengan pemerintahan negara-negara kota orang Kanaan.15 Hal ini dapat dipahami bahwa Ul. 6:4-5 merupakan doktrin monotiesme yang diajarkan Allah kepada bangsa Israel melalui Musa dengan tujuan untuk menyingkirkan paham politeisme dari pemahaman keTuhanan agama Israel, dengan menyatakan bahwa Tuhan itu satu dan tiada yang lain.

Monoteisme (dari bahasa Yunani yaitu kata Monon yang berarti tunggal dan Theos yang berarti Tuhan). Maka Monoteisme artinya kepercayaan bahwa Tuhan adalah satu/tunggal dan berkuasa penuh atas segala sesuatu. ${ }^{16}$ Kalimat "TUHAN itu Allah kita, TUHAN itu esa" dalam Shema Isarel, merupakan pernyataan monoteistis tentang kodrat Allah yang esa, dapat dipahami dengan perintah ganda, yaitu: Pertama; Mengasihi Allah, dan tuntutannya harus dengan segenap hatimu, jiwamu, akal budimu dan kekuatamun (Ul. 6:4-5) karena Allah itu Esa. Kedua; Untuk mengajarkan Shema Israel kepada anak-anak dengan tekun (Ul. 6:6-9) agar mengasihi Allah yang esa. Pesan Allah dalam Ul. 6:4-9, karena konteksnya yang merupakan peringatan supaya para orangtua Israel tidak melupakan Tuhan dengan menyembah ilah lain ketika mendiami tanah Kanaan.

c. Kasihilah TUHAN, Allahmu (Ul. 6:5).

12 Th. C. Vriezen, Agama Isreal Kuno (Jakarta: BPK. Gunung Mulia, 2006), 6.

${ }^{13}$ Hendry C. Thiessen, Teologi Sistematika (Malang: Gandum Mas, 2003), 37.

14 J.I.Packer dkk, Tafsiran Alkitab Wycliffe Volume 1, (Malang: Gandum Mas, 2007), 452.

15 J.I.Packer dkk., Ensiklopedi Fakta Alkitab 1, (Malang: Gandum Mas, 2009), 638.

${ }^{16}$ Sentot Sadono, Doktrin Baptis, Di Antara Pandangan Teologi Kristen, 26. 
Ul. 6:5 tentang tuntutan kasih kepada Allah adalah dengan segenap hatimu, jiwamu, akal budi dan kekuatanmu. Tuntutan kasih kepada Allah harus bermula dari motivai untuk hidup dalam persekutuan dengan Allah, maka ekspresi kasih kepada Allah melibatkan unsur pikiran, emosi, dan kehendak manusia. Musa mengajarkan bangsa Israel untuk hidup taat kepada Allah, sebagai bukti mengasihi Allah karena sebagai ekspresi ketaatan yang dituntut Tuhan dari bangsa Israel. Karena Allah yang bertindak menyelamatkan orang banyak (bangsa Israel) dari perbudakkan dan membuatnya menjadi suatu masyarakat yang tersusun secara baik. ${ }^{17}$ Persekutuan yang intim dengan Allah, merupakan respon atas kasih Allah, yang tergambar dalam kalimat "Kasihilah Tuhan Allahmu". Perintah untuk mengasihi Allah mengandung pengertian bahwa menuruti segala perintah Allah, harus disertai tekad yang bulat, yang memprioritaskan dan memposisikan Tuhan menjadi utama dan tertinggi di dalam kehidupan ini setiap saat.

Christensen mengusulkan sebuah struktur yang terbentuk kosentris bahwa; Perintah terutama: Mengasihi Tuhan (Ul. 6:4-9); Takut akan Tuhan karena Ia adalah Allah yang cemburu (Ul. 6:16-19); Ceritakan kepada anak-anak mengenai peristiwa eksodus dari Mesir (Ul. 6:20-21); Tuhan akan memelihara jika kita menyimpan perintah-perintah-Nya (Ul. 6:23-25). ${ }^{18}$ Berdasarkan struktur ini, yang menonjolkan aspek mengasihi Tuhan, takut akan Tuhan, mengajarkan anak-anak tentang peristiwa keluar dari Mesir dan pemeliharaan Tuhan karena ketaatan kepada Allah, maka penulis dapat dipastikan bahwa Ul. 6:4-9 menempati posisi sangat mendasar dalam keseluruhan komposisi kitab Ulangan.

Dalam peran orangtua sebagai pendidik spiritual anak, dapat mengusahakan materi ajar di era Revolusi Industri 4.0 yang kini menguasai media komunikasi digital, orangtua dapat menggunakan Whatsapp Group, Face book, Instagram, Telegram dan berbagai aplikasi lainnya untuk mengajarkan anak-anaknya tentang mengasihi Allah sebagai esensi dari shema Israel.

\section{Mandat Mendidik (Ul. 6:6-7)}

Ul. 6:6-7 sebagai metode yang dimandatkan Allah kepada orangtua untuk mengajarkan anak-anak secara berulang-ulang tentang Allah itu Esa yang harus dikasihi dengan totalitas hidup kita. Mandat Allah yang harus diperhatikan dan diajarkan secara berulang-ulang kepada anak-anak adalah Ul. 6:4-5. Mandat 1996), 18.

${ }^{17}$ David F. Hinson, Sejarah Israel Pada Zaman Alkitab (Jakarta: BPK. Gunung Mulia,

${ }_{18}$ Duane L. Christensen, Deuteronomy 1 - 11 WBC, Vol. 6A (Dallas Texas: Word Books, 1991), 138. 


\section{JURNAL LUXNOS}

Volume 7 Nomor 1, Juni 2021

Allah didalam Ul. 6:6 mengandung pengertian bahwa pendidikan spiritual anakanak merupakan tanggung jawab orang tua. Cairns menjelaskan bahwa; Ay. 6. "apa yang kuperintahkan" yaitu "kasih" (ay. 5) dan "ketaatan" (ay. 4) harus berjalan seiring sebagai "dengarlah". ${ }^{19}$ Mandat Allah berkaitan dengan tanggung jawab dan peran orang tua bangsa Israel sebagai pendidik kerohani anak-anak. Mandat Allah kepada orangtua Israel untuk mengajarkan anak-anak secara berulang-ulang bangsa Israel dalam Ul. 6:6, merupakan tindak lanjut dari tugas Abraham, Ishak dan Yakub sebagai nenek moyang bangsa Israel, yang mewariskan keteladanan iman kepada keturunan mereka. Sebab kebiasaan orang Israel ialah menceritakan pengalaman hidupnya dengan Allah kepada anak cucunya, dengan harapan generasi anak cucunya juga dapat mengalami pengalaman supranaturalnya dengan Allah.

Orangtua menjadi guru pertama dan utama, yang harus bertanggungjawab untuk mennyediakan kondisi belajar yang aman dan nyaman di rumah buat anak-anak dalam belajar, terlebih menjadi teladan hidup yang diteladani anakanaknya. ${ }^{20}$ Dalam perannya sebagai pendidik spiritual, orangtua Israel harus mampu menciptakan suasana proses pembelajaran yang kondusif bagi anakanak dalam belajar. Dalam mendidik anak-anak untuk mengasihi Allah dengan segenap hati dan dengan segenap jiwa dan dengan segenap kekuatan. orangtua harus menjadi teladan bagi anak-anaknya dalam mengasihi Tuhan, sehingga diteladani dan langsung dipraktek cara hidup mengasihi Tuhan.

Pada zaman Perjanjian Lama pendidikan agama dalam keluarga sebagai fondasi semua pendidikan di masyarakat umat Tuhan. ${ }^{21}$ Tiap generasi bangsa Israel diwajibkan untuk orangtuanya mewariskan peran orangtua sebagai pendidik spiritual anak-anaknya melalui teladan hidupnya dalam mengajarkan shema Israel dengan rajin dan setia. Hubungan anak dan orangtua dengan sangat kuat membentuk sikap anak terhadap Allah. Maka sangat penting adanya hubungan yang baik antara orangtua dengan anak. ${ }^{22}$ Hubungan orangtua dengan anak, sangat mempengaruhi hubungan anak dengan Tuhan. Karena hubungan anak dengan orangtua dapat dirasakan dalam hubungannya dengan Allah. Oleh karena itu, konsep orangtua dalam mendidik anak-anaknya, sangat berpengaruh terhadap konsep anak tentang Allah. Setiap orangtua adalah guru bagi anakanaknya, bukan berarti setiap orangtua harus mengajar seperti guru-guru di sekolah akan tetapi setiap orangtua bisa mengajar anak-anaknya dengan

${ }^{19}$ I. J. Cairns, Tafsiran Alkitab, Kitab Ulangan Pasal 1-11, 134-135.

${ }^{20}$ E.G. Homrighausen \& I.H. Enklaar, Pendidikan Agama Kristen (Jakarta: BPK Gunung Mulia, 2012), 124.

${ }^{21}$ E.G. Homrighausen \& I.H. Enklaar, 130.

${ }^{22}$ Andar Ismail, Ajarlah Mereka Melakukan (Jakarta: BPK. Gunung Mulia, 2002), 170. 
perbuatan dan kata-kata. ${ }^{23}$ Para orangtua lebih efektif mengajarkan anakanaknya lewat keteladanan hidupnya dibanding secara verbal. Setiap orangtua merupakan public figure bagi anak-anaknya dalam iman dan karakter, sebab pengaruh orangtua lebih nyata melalui keteladanan hidupnya.

\section{Metode Mendidik (Ul. 6:8-9)}

Mempelajari metode menjadi penting karena korelasinya yang erat antara apa yang diajarkan dan bagaimana mengajarkan pokok yang dipersiapkan. ${ }^{24}$ Metode pembelajaran merupakan ilmu pengetahuan yang terus berkembang, karena sangat mempengaruhi dalam mengajarkan materi ajar. Metode pembelajaran diprakarsai oleh Allah, dan diwariskan kepada manusia dari generasi ke generasi. Yitro, mertua Musa mengajarkan Musa tentang metode pendelegasian tanggung jawab kepada orang-orang Israel yang dapat dipercaya untuk menjadi pemimpin seribu orang, pemimpin seratus orang, pemimpin lima puluh orang dan pemimpin sepuluh orang agar Musa dan bangsa Israel tidak menjadi lelah (Kel. 18:13-27 band. II Timo. 2:2).

Ulangan 6:7 mengajarkan ungkapan berulang-ulang (harafiah: "meruncingkannya", "mempertajamnya"). Ungkapan ini merupakan instruksi agar sungguh-sungguh mewariskan "kasih" dan "ketaatan" kepada generasi muda ( Ul. 4:9; 6:20-25; 11:19). Metode mengajar yang diterapkan adalah mengajar anak-anak setiap kesempatan, sepanjang hari dan selama hidup. ${ }^{25}$ Metode mengajar yang dimandatkan Allah kepada para orangtua Israel, berhubungan dengan kegiatan kehidupan manusia sehari-hari. Tujuan untuk memudahkan. Semuanya ini disarankan Tuhan, agar orangtua menggunakan apa yang ada padanya dan yang selalu dilakukannya agar memudahkannya dalam mengajarkan shema Israel dan mendidik mereka untuk mengenal dan mengasihi Tuhan. Hal-hal praktis tersebut hanya butuh konsistensi orangtua dalam menerapkan semuanya secara terus menerus dalam mencapai tujuan yang diinginkan Allah untuk dicapai orangtua dalam mendidik anak-anak.

Ayat 7a. "Haruslah engkau mengajarkannya ... kepada anak-anakmu". Unsur kekeluargaan dari administrasi perjanjian mengharuskan bahwa anakanak juga dituntun kepada ketaatan pada peraturan-peraturan yang ada (bdg. 20 dst). Orang saleh harus merenungkan hukum Allah tersebut siang dan malam (ay. 7b-9; band. Mazmur 1:2). ${ }^{26}$ Shema Israel, merupakan perintah Allah yang harus diajarkan dan diwariskan dari generasi ke generasi bangsa Israel dan

\footnotetext{
${ }^{23}$ Melvin A. Jones, Keluarga Yang Bahagia (Surabaya: YAKIN, n.d.), 35.

${ }^{24}$ E. G. Homrighausen \& I. H. Enklaar, Pendidikan Agama Kristen, 72.

25 I. J. Cairns, Tafsiran Alkitab, Kitab Ulangan Pasal 1-11, 134-135.

${ }^{26}$ J.I.Packer dkk, Tafsiran Alkitab Wycliffe Volume 1, 425.
} 
agama Alkitabiah dan moralitas sebagai pernyataan terbaiknya kepada Allah yang Esa. Karena itu pembahasan tentang shema Israel tidak terlepas dari metode pengajaran bagi anak-anak bangsa Israel yang merupakan tanggung jawab orangtua. Pada bagian ini akan dibahas tentang shema Israel dan metode pengajarannya yang merupakan tanggung jawab orangtua dalam mengajarkan Firman Tuhan kepada anak-anaknya.

Pendidikan merupakan topik yang tidak dapat dipisahkan dari sejarah kehidupan manusia. Secara sederhana, pendidikan dapat diartikan sebagai sebuah proses belajar-mengajar, memberikan dan menghasilkan pengetahuan dan keahlian. Berbagai upaya dari orangtua untuk mengajarkan pengetahuannya, pengalamannya, kecakapannya, serta ketrampilannya kepada anak-anaknya, merupakan upaya untuk mempersiapkan kehidupan masa depan baik jasmaniah maupun rohani anak-anaknya.

Ul. 6:8-9 merupakan peragaan media pembelajaran yang diikat ditangan, didahi, pada pintu rumah dan juga pintu gerbang (Kel. 13:9,16; Ul. 11:18). ${ }^{27}$ Pada Ul. 6:7, Tuhan memandatkan kepada orangtua dalam peran sebagai pendidik untuk mewujudkan mandat-Nya menggunakan metode-metode simbolis. Namun, karena hukum Taurat telah dijadikan sebagai panduan dalam mengendalikan totalitas kehidupan umat Allah, maka hukum Taurat yang mengatur tentang kehidupan pribadi, keluarga, rumah tangga, pergaulan hidup, bahkan angota-anggota tubuh dan berbagai kegiatan umat Allah. Kemudian metode berkembangan dari hal-hal harafia ke hal-hal konkrit untuk mengajar dan mendidik anak-anak dengan firman Tuhan secara factual agar lebih mudah mengerti, memahami dan melakukan.

Kemudian diterapkan secara harafiah dengan membuat kota kecil dari kulit (Ibrani: "tefillim") lalu ayat-ayat torat lalu diikatkan ditangan kiri, didahi digantung dipintu rumah dan pintu gerbang. Kotak yang di dahi itu dibagi dalam empat ruang yang masing-masing memuat Kel. 13:1-10 atau Kel.13:11-16 atau Ul. 6:4-9 atau Ul. 11:13-21. Kotak yang diikat pada tangan itu terdiri dari satu ruang saja, dan memuat petikan-petikan tora yang sama. Kotak-kotak inilah yang disebut "tali sembahyang" dalam injil Matius 23:5. Kotak kecil pada pintu rumah bagian kanan terbuat dari logam yang disebut "mezuza". Isi mezuza sama dengan tefillim. Kemungkinan "Mezuza" sebagai pengganti dari darah yang dibubuhkan diambang pintu pada saat peristiwa paskah, misalnya Kel. 12:7.28 Metode-metode yang dimandatkan Allah baik secara simbolis maupun secara harafiah merupakan hal-hal praktis yang sudah menjadi kebiasaan bagi umat 


\section{JURNAL LUXNOS}

Volume 7 Nomor 1, Juni 2021

Allah. Oleh karena itu, para orangtua dalam peran sebagai pendidik anak-anak harus mampu memahami cara aplikasinya agar menjadi lebih efektif dan efisien.

Metode orangtua Israel dalam mendidik anak-anak berdasarkan tuntutan shema Israel sesuai Ul. 6:4-9, terdapat dua prinsip dasar, yaitu: Pertama; Pendidikan anak harus berkaitan dengan Shema Israel, dan Kedua; Shema Israel harus diajarkan dengan penuh bertanggung jawab. "Ul. 6:4-5 merupakan kunci iman kaum Yahudi hingga saat ini, sehingga perlu terus dihafalkan dan dilafalkan seumur hidup, agar tidak menyembah ilah-ilah lain."29 Maka salah satu metode orangtua bangsa Israel dalam mendidik anak-anaknya adalah mengahafalkan shema Israel. Untuk mewujudkan metode menghafal ini, perlu peran serta orangtua, karena sebagai hak dan kewajiban utamanya dalam mendidik anak-anaknya.

Pendidikan dalam bentuk apa pun dipelihara oleh generasi muda untuk hidup, baik di dalam keluarga maupun di dalam komunitas yang lebih luas. ${ }^{30}$ Supaya anak-anak dapat memelihara pendidikan yang diterimanya, maka merupakan hak dan kewajiban orangtua yang bersifat asali dan utama terhadap pendidikan anak-anaknya. Karena metode yang dipakai setiap orangtua dalam mengajarkan anak-anaknya, menyangkut keistimewaan hubungan cinta kasih antara orangtua dan anak-anak. Oleh sebab itu, Allah menekankan dalam shema Israel, agar orangtua bertanggung jawab dan memahami berbagai metode dalam mengajarkan shema Israel kepada anak-anaknya. Dengan demikian, maka keluarga merupakan sentral Pendidikan pertama dan utama dalam dunia pendidikan serta orangtua sebagai pendidiknya atau guru yang pertama dan utama. Karena pendidikan bagi anak dalam keluarga sebagai bentuk ekspresi cinta kasih dari orangtua dalam menjalankan mandat Allah.

Bagi bangsa Israel, pendidikan spiritual anak sebagai kegiatan yang menyatu dengan kehidupan mereka karena perjanjian Allah dengan bangsa Israel itu. Karena sangat pentingnya pendidikan kerohanian bagi pertumbuhan iman anak-anak orang Yahudi, maka orang Yahudi memberikan sekitar 320-380 jam setiap tahun hanya untuk pendidikan agama bagi anak mereka. ${ }^{31}$ Jika ditelusuri, maka waktu yang disediakan orang-orang tua Yahudi untuk mengajar anak-anak tentang Firman Tuhan kurang lebih satu jam setiap harinya. Sebab itu di dalam Alkitab sudah dikatakan bahwa Tuhan telah mengajarkan kepada orang Yahudi dewasa untuk mendidik anak-anaknya dengan Taurat Tuhan (Ul. 6:4-9). Bila dibandingkan dengan Pendidikan Agama Kristen bagi anak-anak keluarga-keluarga Kristen saat ini, maka ditemukan bahwa di sekolah hanya 1

\footnotetext{
${ }^{29}$ Jeane Ch. Obadja, Survei Ringkas Perjanjian Lama (Surabaya: Momentum, 2004), 20.

${ }^{30}$ Hope S. Antone, Pendidikan Kontekstual (Jakarta: BPK. Gunung Mulia, 2002), 17.

${ }^{31}$ Stephen Tong, Arsitektur Jiwa (Jakarta: LRII, 1991), 13.
} 
jam 30 menit belajar Pendidikan Agama Kristen setiap minggunya, berarti hanya 78 jam dalam setahun belajar Pendidikan Agama Kristen di sekolah. Ditambah 1 jam belajar Pendidikan Agama Kristen di sekolah Minggu pada setiap minggunya, berarti hanya 52 jam belajar Pendidikan Agama Kristen dalam setahun di sekolah minggu. Jadi total waktu untuk anak-anak Kristen belajar firman Tuhan saat sekolah dan saat sekolah minggu hanya 130 jam dalam setahun. Dengan demikian, maka kebutuhan firman Tuhan bagi anak-anak masih sangat minim, maka harus menjadi tanggung jawab orang tua untuk mengajarkan firman Tuhan kepada anak-anak di rumah.

Adapun prinsip-prinsip penting yang dapat diterapkan dalam mendidik anak berdasarkan kitab Ul. 6:6-9 adalah sebagai berikut; Pertama; Dalam tradisi dan agama Yahudi, mendidik anak merupakan tanggung jawab orangtua. Kedua; Orangtua harus bisa menjadi figur yang dapat diteladani oleh anak-anaknya. Karena anak-anak belajar tidak hanya secara teori yang didengarnya, tetapi terutama dari keteladanan hidup yang dilihat dan dialaminya lewat orangtuanya. Ketiga; Tujuan mendidik anak dalam firman Tuhan agar anak mampu memberikan respons terhadap kasih Allah dengan mengasihi-Nya dengan segenap hati, dan dengan segenap jiwa dan dengan segenap kekuatan. Keempat; Orangtua harus bersedia untuk belajar dan menyediakan waktu yang memadai, untuk mengajarkan anak-anaknya berulang-ulang, (Ul. 6:7). Kelima; Orangtua harus bersedia bergaul dengan anak-anaknya agar bisa mengajarkan keteladanan hidup dalam mengasihi Allah dalam berbagai situasi kehidupan secara konkret (Ul.6:7).

\section{Mendidik Spiritual Anak di Era Revolusi Industri 4.0}

Indikator era revolusi industri 4.0 terlihat dari konektivitas dan interaksi yang semakin meningkat karena sistem digital, kecerdasan artifisial, dan virtual yang sangat cepat perkembangannya. Perkembangan teknologi membawa perubahan sangat cepat, manusia dituntut untuk menguasai teknologi informasi dan komunikasi sebagai kebutuhan dalam perekembangan zaman. Perkembangan teknologi komunikasi berdampak pada perubahan pada semua sektor kehidupan manusia, termasuk pendidikan spiritual.

Perubahan di era revolusi industri 4.0 menuntut peningkatan Sumber Daya Manusia (SDM) agar menyesuaikan kemampuan untuk bersaing secara global. Peningkatan kualitas SDM melalui jalur pendidikan mulai dari pendidikan dasar dan menengah hingga ke perguruan tinggi adalah kunci untuk mampu mengikuti 
perkembangan Revolusi Industri 4.0.32 Sistem komunikasi di era revolusi industri 4.0 yang berbasis digital, menimbulkan perubahan dalam pelaksanaan pendidikan dari konvensional menjadi virtual. Perubahan ini menuntut orangtua sebagai pengajar spiritual pertama bagi anak-anaknya untuk harus berusaha untuk mengikuti perubahan karena perkembangan zaman.

Lase mengatakan bahwa Literasi data adalah kemampuan untuk membaca, analisa dan menggunakan informasi dari data dalam dunia digital. Kemudian, literasi teknologi adalah kemampuan untuk memahami sistem mekanika dan teknologi dalam dunia kerja. Sedangkan literasi sumber daya manusia yakni kemampuan berinteraksi dengan baik, tidak kaku, dan berkarakter. ${ }^{33}$ Dalam menerapkan Ul. 6:4-9 di era revolusi industri 4.0 para orangtua generasi milenial perlu memahami literasi yang dipakai untuk mempersiapkan, mengajarkan dan mendidik anak-anak berbasis data elektronik.

Orangtua sebagai pendidik spiritual anak era revolusi industri 4.0, dituntut untuk kreatif, inovatif, serta kompetitif dalam mengajar, mendidik dan memberi teladan bagi anaknya dengan menggunakan berbagai bentuk media komunikasi digital yang serba online. Tujuannya agar anak-anak bertumbuh imannya tidak menjadi korban penggunaan media komunikasi online. Proses mendidik spiritual anak di era revolusi industri harus respons terhadap kebutuhan revolusi industri 4.0, karena peran teknologi disejajarkan dengan manusia dalam menciptakan metode-metode baru dalam pembelajaran dengan kreatif dan inovatif termasuk dalam mendidikan spiritual dan karakter anak.

Orangtua harus mempersiapkan dan mengaplikasikan materi ajar dengan mengunduh film-film animasi rohani dan film-film kartun rohani sesuai materi ajar agar dapat mengajarkan anak-anaknya tentang firman Tuhan dengan maksimal sesuai perkembangan zaman di era revolusi industri 4.0.

\section{Kesimpulan}

Pelaksanaan pendidikan agama bagi bangsa Israel dilandaskan dan berpusat pada: (1). Identitasnya sebagai umat pilihan Allah; (2). Penyataan diri Allah (wahyu dan pengalaman spiritual dengan Allah); (3). Pernyataan sebagai gambar Allah. Ketiga poin ini harus dikuasai orang Israel agar mengajarkan anak-anaknya setiap saat (Ul. 6:4-9), dengan tujuan agar generasi muda lebih cenderung bersandar kepada Allah yang menyatakan diri melalui firman-Nya,

\footnotetext{
32 Delipiter Lase, "Pendidikan Di Era Revolusi Industri 4.0," SUNDERMANN: Jurnal Ilmiah Teologi, Pendidikan, Sains, Humaniora Dan Kebudayaan 1, no. 1 (2019): 28-43, https:/ / doi.org/10.36588/sundermann.v1i1.18.

${ }^{33}$ Lase.
} 
dan sedapat mungkin mengalami peristiwa-peristiwa sejarah faktual dan perbuatan-perbuatan yang supranatural yang dialami nenek moyangnya.

Prinsip-prinsip mendidik anak berdasarkan kitab Ul. 6:6-9; (1). Tanggung jawab orangtua. (2). Orangtua menjadi teladan bagi anak-anaknya. (3). Tujuan mendidik spiritual anak agar mampu meresponsi kasih Allah dengan mengasihi Allah dengan segenap hati, jiwa, akal budi dan kekuatan. (4). Orangtua harus berulang-ulang mengajarkan firman Tuhan kepada anak-anaknya, (Ul. 6:7). (5). Orangtua harus bersedia bergaul dengan anak-anaknya agar bisa mengajarkan keteladanan hidup dalam mengasihi Allah dalam berbagai situasi kehidupan secara konkret (Ul.6:7).

Penerapan Ul. 6:4-9 dalam mendidik spiritual anak oleh para orangtua milenial masih sangat relevan di era revolusi industri 4.0, karena konten materi ajar tetap sama yaitu bersumber dari Alkitab, hanya media dan metode ajar yang perlu disesuaikan dengan tuntutan perkembangan zaman. Karena konteks Musa menulis Ulangan 6:4-9 sangat berbeda dengan konteks saat ini di era revolusi industri 4.0.

Para orangtua generasi milenial, dituntut untuk kreatif dan inovatif dalam menerapkan Ul. 6:4-9 dalam mendidik spiritual anak, seperti mengunduh filmfilm animasi dan kartun rohani yang menarik minat dan perhatian anak-anak dalam belajar firman Tuhan sesuai dengan kebutuhan di era revolusi industri 4.0. Namun, perlu pendampingan dari orangtua untuk menjelaskan setiap konten yang dipelajari dalam bentuk film, sehingga makna rohaninya dimengerti anakanak.

\section{Referensi}

Antone, Hope S. Pendidikan Kontekstual. Jakarta: BPK. Gunung Mulia, 2002.

Bahasa, Pusat. Kamus Besar Bahasa Indonesia, 2011. http://www.kamusbesar.com/38643/surealisme.

Boehlke, Robert R. Sejarah Perkembangan Pikiran Dan Praktek Pendidikan Agama Kristen Dari Plato Sampai IG. Loyola,. Jakarta: BPK Gunung Mulia, 2006.

Christensen, Duane L. Deuteronomy 1 - 11 WBC, Vol. 6A. Dallas Texas: Word Books, 1991.

Cully, Iris V. Dinamika Pendidikan Kristen. Jakarta: BPK. Gunung Mulia, 2014.

D. A. Hubbard dkk. Pengantar Perjanjian Lama 1,. Jakarta: BPK. Gunung Mulia, 2010.

David F. Hinson. Sejarah Israel Pada Zaman Alkitab. Jakarta: BPK. Gunung Mulia, 1996. 
Dyrness, William. Tema-Tema Dalam Teologi Perjanjian Lama,. Malang: Gandum Mas, 1979.

E.G. Homrighausen \& I.H. Enklaar. Pendidikan Agama Kristen. Jakarta: BPK Gunung Mulia, 2012.

E.W. Nichoson. Deuteronomy and Tradition. Philadelphia: Fortress, n.d.

Hellen Chou Pratama. Cyber Smart Parenting: Kiat Sukses Menghadapi Dan Mengasuh GENERASI DIGITAL. Bandung: Visi Pres, 2002.

Hendry C. Thiessen. Teologi Sistematika. Malang: Gandum Mas, 2003.

I. J. Cairns. Tafsiran Alkitab, Kitab Ulangan Pasal 1-11. Jakarta: BPK. Gunung Mulia, 2008.

Ismail, Andar. Ajarlah Mereka Melakukan. Jakarta: BPK. Gunung Mulia, 2002.

J.I.Packer dkk. Tafsiran Alkitab Wycliffe Volume 1. Malang: Gandum Mas, 2007.

Lase, Delipiter. "Pendidikan Di Era Revolusi Industri 4.0." SUNDERMANN: Jurnal Ilmiah Teologi, Pendidikan, Sains, Humaniora Dan Kebudayaan 1, no. 1 (2019): 28-43. https://doi.org/10.36588/sundermann.v1i1.18.

Martinus T. Mawene. Perjanjian Lama Dan Teologi Kontekstual. Jakarta: BPK. Gunung Mulia, 2008.

Melvin A. Jones. Keluarga Yang Bahagia. Surabaya: YAKIN, n.d.

Obadja, Jeane Ch. Survei Ringkas Perjanjian Lama. Surabaya: Momentum, 2004.

Santoso, Samuel. Berteologi Di Tengah Perubahan. Jakarta: Sinode GKI, 2007.

Sentot Sadono. Doktrin Baptis, Di Antara Pandangan Teologi Kristen. Semarang: Psca Sarjara STBI, 2011.

Stephen Tong. Arsitektur Jiwa. Jakarta: LRII, 1991.

Th. C. Vriezen. Agama Isreal Kuno. Jakarta: BPK. Gunung Mulia, 2006.

Tong, Stephen. Membesarkan Anak Dalam Lindungan Tuhan. Surabaya: Momentum, 2015.

Tony Evans. Teologi Allah. Malang: Gandum Mas, 1999.

Wolf, Herbert. Pengenalan Pentateukh. Malang: Gandum Mas, 2004. 